\title{
ANALISA PENGARUH SELF IMAGE CONGRUITY, RETAIL SERVICE QUALITY, DAN CUSTOMER PERCEIVED SERVICE QUALITY TERHADAP REPURCHASE INTENTION DENGAN CUSTOMER SATISFACTION SEBAGAI VARIABEL INTERVENING DI BROADWAY BARBERSHOP SURABAYA
}

\author{
Livia Margarita Widjiono ${ }^{1}$; Edwin Japarianto ${ }^{1^{*}}$ \\ Program Manajemen Pemasaran, Fakultas Ekonomi, Universitas Kristen Petra \\ Jl. Siwalankerto 121-131, Surabaya \\ E-mail:m36411005@john.petra.ac.id; edwinj@petra.ac.id \\ *Korespondensi penulis
}

\begin{abstract}
Abstrak: Penelitian ini bertujuan untuk menganalisa pengaruh dari Self Image Congruity, Retail Service Quality, dan Customer Perceived Service Quality terhadap Repurchase Intention dengan Customer Satisfaction sebagai variabel intervening di Broadway Barbershop Surabaya. Penelitian ini menggunakan 100 responden dan metode path analysis. Hasil penelitian membuktikan bahwa tidak terdapat pengaruh yang signifikan dari Self Image Congruity terhadap Customer Satisfaction, terdapat pengaruh yang signifikan dari Retail Service Quality terhadap Customer Satisfaction, tidak terdapat pengaruh yang signifikan dari Customer Perceived Service Quality terhadap Customer Satisfaction, terdapat pengaruh yang signifikan dari Customer Satisfaction terhadap Repurchase Intention, terdapat pengaruh yang signifikan dari Self Image Congruity terhadap Repurchase Intention, terdapat pengaruh yang signifikan dari Customer Perceived Service Quality terhadap Repurchase Intention.
\end{abstract}

Kata kunci: Self Image Congruity, Retail Service Quality, Customer Perceived Serviced Quality, Customer Satisfaction, Repurchase Intention.

\begin{abstract}
This study aims to analyze the influence of Self Image Congruity, Retail Service Quality, and Customer Perceived Service Quality on Repurchase Intention with Customer Satisfaction as intervening variable. This study uses 100 respondents and path analysis method. The research result obtained, there is no significant effect of Self Image Congruity on Customer Satisfaction, there is a significant effect of Retail Service Quality on Customer Satisfaction, there is no significant effect of Customer Perceived Service Quality on Customer Satisfaction, there is a significant effect of Customer Satisfaction on Repurchase Intention, there is a significant effect of Self Image Congruity on Repurchase Intention, there is a significant effect of Customer Perceived Service Quality on Repurchase Intention.
\end{abstract}

Keywords: Self Image Congruity, Retail Service Quality, Customer Perceived Serviced Quality, Customer Satisfaction, Repurchase Intention

\section{PENDAHULUAN}

Bisnis retail di Indonesia mengalami pergeseran perilaku yang signifikan dalam beberapa tahun terakhir ini. Sebelum adanya pergeseran perilaku ini, konsumen hanya fokus utnuk memenuhi kebutuhan sehari-hari, namun setelah adanya pergeseran perilaku ini semakin beragam kebutuhan konsumen. Pergeseran perilaku konsumen yang berubah juga terjadi di Surabaya.

Jenis Retail di Surabaya bermacam-macam, mulai dari retail makanan, kebutuhan sehari-hari hingga retail dibidang fashion. Salah satu jenis retail fashion yang berkembang sekarang ini adalah industri salon. Seiring dengan perkembangan jaman tumbuh usaha salon khusus untuk pria yang biasa disebut Barbershop.

Usaha Barbeshop memiliki peluang yang sangat baik, terbukti dengan banyaknya barbershop yang tersebar diseluruh penjuru kota. Broadway Barbershop adalah salah satu salon khusus pria di Surabaya. Target utama Broadway sendiri adalah lebih kepada pria yang berusia 20 tahun keatas. Design interior Broadway Barbershop yang classy, tembok ruangan yang hanya bermotif batu bata berwarna putih, pintu yang terbuat dari kayu serta jendela kayu dan terdapat logo Broadway Barbershop. Selain itu, tukang cukur (cutter) juga menggunakan seragam yang casual dan santai sehingga membuat para pria menjadi nyaman dan tidak terkesan. Broadway Barbershop berusaha untuk melayani konsumen dengan maksimal.

Adanya konsep tentang penilaian suatu kualitas pelayanan lebih didasarkan pada terbentuknya persepsi seseorang terhadap kualitas tersebut. Persepsi terhadap kualitas layanan atau produk sendiri dapat didefinisikan sebagai persepsi pelanggan terhadap keseluruhan kualitas atau keunggulan suatu layanan atau produk berkaitan dengan apa yang diharapkan 
oleh pelanggan (Durianto, Sugiarto, \& Sitinjak, 2001). Persepsi terhadap kualitas di Broadway Barbershop sendiri bagi pria adalah maskulin, dimana pria dapat lebih percaya diri untuk merapikan rambutnya karena mulai dari atmosfer hingga tukang cukur berpakaian lebih casual. Model rambut yang diikuti di Broadway Barbershop juga lebih mengikuti model rambut pria yang sedang trend saat ini

Self Image Congruence bagi kaum laki-laki dijaman yang berkembang ini, merapikan rambut di bawah pohon mereka merasa enggan dikarenakan kurang nyaman dan kurang bergengsi, dilain sisi merapikan rambut di salon biasa, mereka takut dianggap feminim karena kebanyakan pengunjung dan karyawan adalah wanita, Oleh karena itu barbershop membantu laki-laki dalam merapikan rambut dan diri mereka dan mencerminkan bagaimana citra diri kaum laki-laki.

Dari latar belakang yang dikemukakan maka penelitian ini mencoba untuk meneliti hal tersebut yaitu dengan mengambil topik yang berkaitan dengan "Analisa Pengaruh Self Image Congruity, Retail Service Quality, dan Customer Perceived Service Quality terhadap Repurchase Intention dengan Customer Satisfaction sebagai Variabel Intervening”.

Berdasarkan fenomena di atas dapat disimpukan beberapa permasalahan penelitian sebagai berikut:

1. Apakah Self Image Congruity berpengaruh terhadap Customer Satisfaction di Broadway Barbershop?

2. Apakah Retail Service Quality berpengaruh terhadap Customer Satisfaction di Broadway Barbershop?

3. Apakah Customer Perceived Service Quality berpengaruh terhadap Customer Satisfaction di Broadway Barbershop?

4. Apakah Customer Satisfaction berpengaruh terhadap Repurchase Intention di Broadway Barbershop?

5. Apakah Self Image Congruity berpengaruh terhadap Repurchase Intention di Broadway Barbershop?

6. Apakah Customer Perceived Service Quality berpengaruh terhadap Repurchase Intention $\mathrm{di}$ Broadway Barbershop?

\section{URAIAN PENELITIAN}

\section{Self Image Congruity}

Setiap orang yang memiliki citra diri yang khas. Citra diri yang khas tersebut merupakan hasil dari perkembangan latar belakang dan pengalaman individu tersebut. Citra merupakan salah satu dasar yang digunakan konsumen untuk menentukan seberapa cocok kepribadian mereka dengan citra ritel tertentu (Lindquist \& Sirgy, 2009).

Self Image Congruity terdiri dari empat dimensi (Schiffman \& Kanuk, 2008), yaitu:

- Actual Self Congruity, konsep diri yang telah ditunjukan oleh individu pada saat ini.

- Social Self Congruity, konsep diri yang secara nyata telah ditunjukan individu pada lingkungannya dalam upaya mengaktualisasikan diri.

- Ideal Self Congruity, konsep diri yang sebenarnya ingin dicapai oleh individu dalam kehidupan pribadinya.

- Ideal Social Self Congruity, konsep diri yang mendorong individu untuk menunjukkan sisi ideal dari dirinya.

\section{Retail Service Quality}

Kualitas pelayanan dapat diartikan sebagai upaya pemenuhan kebutuhan dan keinginan konsumen serta ketepatan penyampaiannya dalam mengimbangi harapan konsumen (Tjiptono, 2007).

Terdapat lima elemen retail service quality, diantaranya adalah physical aspects, reliability, personal interaction, problem solving, dan policy (Kaul, 2005).

\section{Physical Aspects}

Aspek fisik dari retail yang meliputi berbagai perlatan-peralatan atau fasilitas yang bersifat tangibles dan mempengaruhi kualitas layanan yang diberikan kepada pelanggan.

2. Reliability

Konsistensi retail dalam memberikan layanan kepada pelanggan terlebih lagi dihubungkan dengan janji yang diberikan kepada pelanggan.

3. Personal Interaction

Kemampuan untuk menjalin hubungan yang harmonis dengan pelanggan, dan hubungan ini diarahkan untuk bisa memuaskan pelanggan.

\section{Problem Solving}

Problem solving dinilai dari kemampuan yang dimiliki oleh peretail untuk menyelesaikan berbagai masalah yang dihadapi pelanggan. Problem solving merupakan evaluasi kualitas layanan yang didasarkan pada kemampuan untuk bisa peduli dan mampu memberikan penyelesaian atas berbagai masalah yang dihadapi oleh pelanggan.

5. Policy

Policy adalah berbagai kebijakan yang ditetapkan untuk memberikan kemudahan, kenyamanan bagi 
pelanggan. Policy ditetapkan untuk bisa memberikan layanan yang terstandarisasi bagi pelanggan.

\section{Customer Perceived Service Quality}

Perceived service quality menurut (Bitner \& Zeithaml, 2003) merupakan dasar dari terbentuknya sebuah kualitas dan dapat digunakan untuk mengukur kepuasan pelanggan.

Pelanggan adalah subyek yang menilai dan mengevaluasi sebuah kulitas layanan (Bitner \& Zeithaml, 2003) yang didasarkan pada:

1. Kualitas interaksi yaitu kualitas yang berhubungan erat dengan bagaimana proses layanan yang disampaikan yaitu dilihat dari proses interaksi staff penyedia layanan terhadap pelanggannya.

2. Kualitas lingkungan fisik yaitu sebuah kualitas yang ada di dalam lingkungan di mana proses pelayanan itu terjadi.

3. Kualitas hasil yaitu apa yang pelanggan dapatkan, ketika proses produksi servis dan interaksi anatara pelanggan dengan penyedia layanan selesai.

\section{Customer Satisfaction}

Kepuasan pelanggan adalah "Satisfaction is the consumer's fulfillment response. It is a judgement that a product or service feature, or the product or service itself, provides a pleasurable level of consumptionrelated fulfillment" (Zeithaml, 2011). Di tafsirkan definisi ini berarti kepuasan yang mengevaluasi pelanggan dari produk atau jasa dalam hal apakah produk atau jasa itu telah memenuhi kebutuhan pelanggan dan harapan.

Terdapat tiga dimensi dalam mengukur kepuasan pelanggan secara universal (Zeithaml, 2011), yaitu:

1. Fulfillment, rasa kepuasan dalam pengetahuan bahwa kebutuhan seseorang terpenuhi

2. Pleasure, perasaan senang untuk layanan yang membuat konsumen merasa baik atau berhubungan dengan rasa bahagia, kepuasan bisa berarti menyenangkan.

3. Ambivalence, rasa kepuasan ketika ada campuran pengalaman positif dan negative yang terkait dengan produk atau jasa.

\section{Repurchase Intention}

Pembelian ulang adalah kegiatan pembelian yang dilakukan lebih dari satu kali atau beberapa kali (Peter, Paul, \& Olson, 2002). Kepuasan yang didapatkan oleh konsumen, dapat mendorong dan memotivasi konsumen untuk melakukan pembelian ulang.
Ada beberapa indikator yang mempengaruhi minat seseorang untuk melakukan pembelian ulang (Mangkunegara, 2000), yaitu:

1. Psikologis

Meliputi pengalam individu tentang kejadian di masa lalu, yang akan berpengaruh merubah perilaku individu tersebut di masa depan.

2. Pribadi

Kepribadian konsumen akan mempengaruhi persepsi dan keputusan dalam membeli produk atau jasa.

3. Sosial

Suatu kelompok orang (keluarga, komunitas, atau orang tertentu) yang mempengaruhi sikap, pendapat, dan perilaku konsumen.

\section{Kerangka Konseptual}

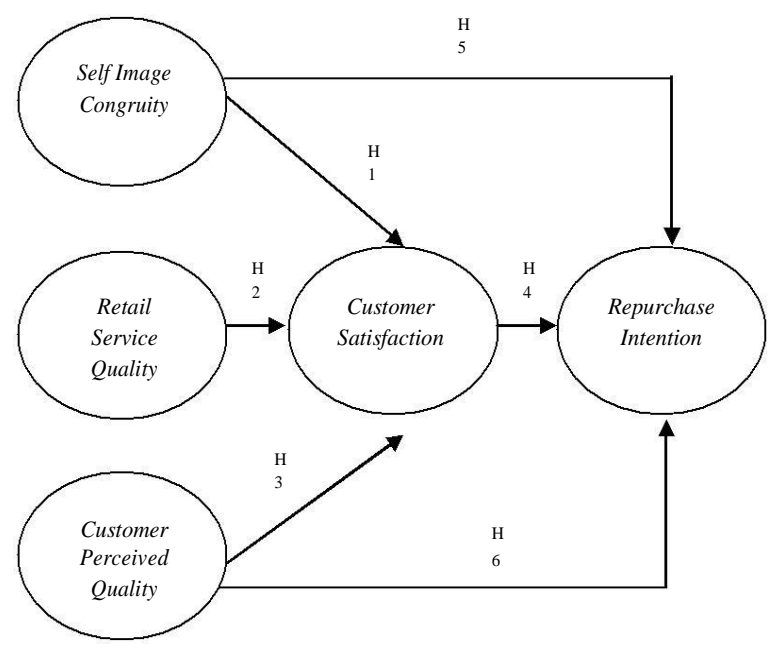

Gambar 1. Kerangka Konseptual

\section{Hipotesis}

Adapun hipotesis yang diajukan pada penelitian ini adalah:

H1: Ada pengaruh positif antara variable Self Image Congruity terhadap Customer Satisfaction

H2: Ada pengaruh positif antara variable Retail Service Quality terhadap Customer Satisfaction.

H3: Ada pengaruh positif antara variable Customer Perceived Quality terhadap Customer Satisfaction

H4: Ada pengaruh positif antara variable Customer Satisfaction terhadap Repurchase Intention.

H5: Ada pengaruh positif antara variable Self Image Congruity terhadap Repurchase Intention.

H6: Ada pengaruh positif antara variable Customer Perceived Quality terhadap Repurchase Intention. 


\section{METODE PENELITIAN}

\section{Populasi dan Sampel}

Populasi adalah kumpulan dari seluruh elemen sejenis tetapi dapat dibedakan satu sama lain karena karakteristiknya (Suprapto, 2008). Populasi yang menjadi sasaran dalam penelitian ini adalah seluruh konsumen pria yang sudah pernah merapikan rambut di Broadway Barbershop Surabaya.

Sampel merupakan sebagian dari populasi yang memiliki cirri yang sama dengan populasi (Purwanto, 20011). Untuk teknik pengambilan sampel, peneliti menggunakan teknik non-probability sampling dengan menggunakan metode purposive sampling atau judgmental sampling. Judmental sampling memilih sampel berdasarkan penilaian terhadap beberapa karakteristik anggota sampel yang disesuaikan dengan maksud penelitian (Kuncoro M., 2003). Sampel yang digunakan diambil dari populasi yang memiliki karakteristik sebagai berikut: Konsumen yang minimal pernah dua kali merapikan rambut di Broadway Barbershop dalam 3 bulan terakhir.

Penelitian ini menggunakan sampel sebanyak 100 responden, dengan berdasarkan pertimbangan tingkat keyakinan dengan $\alpha 95 \%$ dan kesalahan yang mungkin terjadi tidak lebih dari $10 \%$.

\section{Definisi Operasional Variabel}

\section{Self Image Congruence (X1)}

\section{Actual Self Congruity}

Mengukur keadaan aktual diri konsumen sendiri saat setelah memotong rambut di Broadway Barbershop

2. Social Self Congruity

Mengukur bagaimana konsumen yang telah memotong rambut di Broadway Barbershop di pandangan orang lain.

3. Ideal Self Congruity

Mengukur keadaan konsumen secara ideal setelah memasuki Broadway Barbershop.

4. Ideal Social Self Congruity

Mengukur bagaimana keadaan ideal orang lain melihat diri konsumen setelah memotong di Broadway Barbershop.

\section{Retail Service Quality (X2)}

\section{Physical Aspects}

Mengukur kelengkapan dan design ruangan secara fisik.

2. Reliability

Mengukur keahlian Broadway Barbershop dalam mengikuti trend yang sedang berkembang saat ini.

\section{Personal Interaction}

Mengukur interaksi antara karyawan dengan konsumen Broadway Barbershop.

4. Problem Solving

Mengukur tanggapan karyawan Broadway Barbershop apabila konsumen mengalami masalah.

5. Policy Mengukur kebijakan di Broadway Barbershop untuk kenyamanan konsumen.

Customer Perceived Service Quality (X3)

1. Kualitas interaksi

Mengukur bagaimana layanan yang disampaikan melalui interaksi antara karyawan dengan konsumen di Broadway Barbershop.

2. Kualitas lingkungan fisik

Mengukur kualitas lingkungan di Broadway Barbershop.

3. Kualitas hasil

Mengukur hasil yang didapatkan oleh konsumen di Broadway Barbershop.

Variabel intervening adalah:

- Customer Satisfaction (Y1). Mengukur kepuasan konsumen sebelum dan sesudah merapikan rambut di Broadway Barbershop.

- Variabel terikat adalah: Repurchase Intention (Y2). Mengukur adanya minat bagi konsumen untuk melakukan pembelian ulang dan mengajak orang lain untuk datang dan merapikan rambut di Broadway Barbershop.

\section{Teknik Analisis Data}

Pengujian hipotesis pada penelitian ini dilakukan dengan menggunakan teknik path analysis. Pengujian statistic pada model path analysis dalam penelitian ini dilakukan dengan menggunakan metode partial least square regression. Pengolahan data menggunakan program smart PLS.

\section{HASIL PENELITIAN DAN PEMBAHASAN}

\section{Profil Responden}

Berikut merupakan analisa deskirptif profil responden dari penelitian ini, dari total 100 responden dapat diketahui:

Tabel 1. Profil Responden

\begin{tabular}{lll} 
& Prosentase & \\
\hline & & $(\%)$ \\
\hline Tempat & Surabaya Timur & $21 \%$ \\
Tinggal & Surabaya Barat & $50 \%$ \\
Usia & 21-30 Tahun & $64 \%$ \\
& 31-40 Tahun & $19 \%$ \\
Pekerjaan & Pelajar/Mahasiswa & $35 \%$ \\
& Wirausaha & $34 \%$ \\
\hline
\end{tabular}


Tabel 1 Menunjukkan bahwa paling banyak responden yang datang untuk merapikan rambut bertempat tinggal di Surabaya Barat sebanyak 50\% dengan usia 21-30 tahun sebanyak 64\% dan memiliki pekerjaan sebagai pelajar/mahasiswa. Hal ini dikarenakan dua gerai Broadway Barbershop berada di Surabaya Barat. Target Broadway Barbershop sendiri pun adalah berusia di atas 20 tahun, oleh karena itu paling banyak konsumen yang datang di Broadway Barbershop adalah berusia 21-30 tahun dimana pekerjaan mereka paling banyak adalah sebagai pelajar/mahasiswa.

\section{Analisa SEM-PLS}

\section{Analisa Partial Least Square}

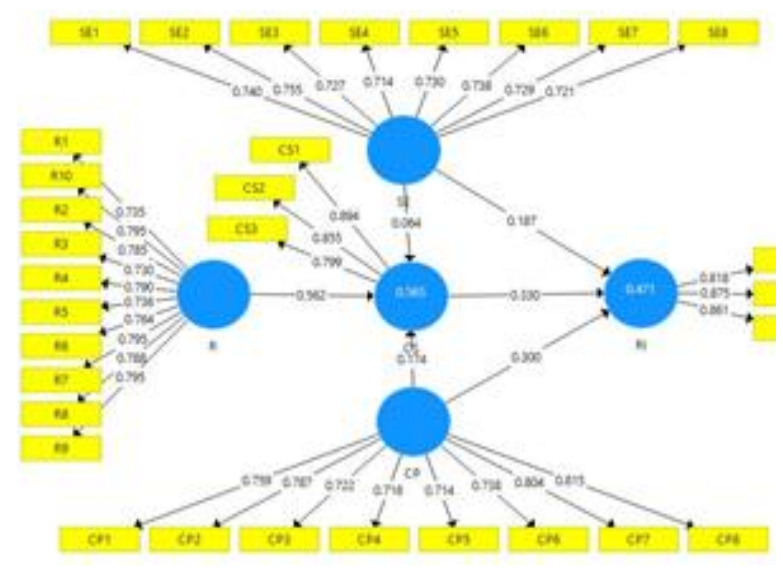

Gambar 2. Output Model Pengukuran PLS

\section{Evaluasi Measurement (Outer) Model}

Uji Validitas

Ada tiga cara untuk menguji validitas tiap indikator, yaitu dengan analisa Average Variance Extracted (AVE).

Tabel 2. Nilai Average Variance Extracted (AVE)

\begin{tabular}{cc}
\hline CP & $\mathbf{0 . 5 7 4}$ \\
CS & 0.723 \\
R & 0.596 \\
RI & 0.725 \\
SE & 0.536 \\
\hline
\end{tabular}

Untuk melihat validasi suatu konstruk dapat juga dengan melalui validitas diskriminan. Validitas dikriminan adalah nilai square root of average variance extracted (AVE). Dianggap valid apabila nilai $>0.5$. Pada Tabel 2 menunjukkan bahwa semua nilai di atas 0.5 .
Uji Reliabilitas

Evaluasi terakhir pada outer model adalah cronbach's alpha. Sebuah variabel dikatakan memenuhi reliabilitas jika memiliki nilai cronbach's alpha $>0.7$ meskipun 0.6 masih dapat diterima.

Tabel 3. Hasil Cronbach's Alpha

\begin{tabular}{cc}
\hline $\mathbf{C P}$ & $\mathbf{0 . 8 9 4}$ \\
$\mathbf{C S}$ & 0.808 \\
$\mathbf{R}$ & 0.925 \\
$\mathbf{R I}$ & 0.810 \\
SE & 0.877 \\
\hline
\end{tabular}

Tabel 3 menunjukkan bahwa nilai cronbach's alpha untuk semua konstruk adalah di atas 0.7, sehingga semua konstruk dikatakan reliable.

\section{Evaluasi Structural (Inner) Model}

Uji R-Square

Tabel 4. Hasil $R$-Square

\begin{tabular}{ccccc}
\hline & $\begin{array}{c}\text { Original } \\
\text { Sample } \\
(\mathrm{O})\end{array}$ & $\begin{array}{c}\text { Sample } \\
\text { Mean } \\
(\mathrm{M})\end{array}$ & $\begin{array}{c}\text { Standard } \\
\text { Error } \\
(\text { STERR) }\end{array}$ & $\begin{array}{c}\mathrm{T} \\
\text { Statistik }\end{array}$ \\
\hline $\mathrm{CS}$ & 0.565 & 0.587 & 0.068 & 8.262 \\
$\mathrm{RI}$ & 0.471 & 0.491 & 0.091 & 5.196 \\
\hline
\end{tabular}

Tabel 4 menjelaskan bahwa CS memiliki nilai $R$-Square sebesar 0.565 yang memiliki arti bahwa $\mathrm{SE}$, $\mathrm{R}$, dan CP mampu menjelaskan konstruk CS sebesar $56.5 \%$. RI memiliki nilai $R$-Square sebesar 0.471 yang memiliki arti bahwa SE, CS, dan CP mampu menjelaskan konstruk RI sebesar $47.1 \%$.

\section{Uji Hipotesa}

Tabel 5. Hasil Uji Hipotesa

\begin{tabular}{lcccc}
\hline & $\begin{array}{c}\text { Original } \\
\text { Sample } \\
(\mathrm{O})\end{array}$ & $\begin{array}{c}\text { Sample } \\
\text { Mean } \\
(\mathrm{M})\end{array}$ & $\begin{array}{c}\text { Standard } \\
\text { Error } \\
(\text { STERR) }\end{array}$ & $\begin{array}{c}T \\
\text { Statistik }\end{array}$ \\
\hline $\mathbf{C P} \rightarrow \mathbf{C S}$ & 0.174 & 0.176 & 0.162 & 1.072 \\
$\mathbf{C P} \rightarrow \mathbf{R I}$ & 0.300 & 0.302 & 0.120 & 2.494 \\
$\mathbf{C S} \rightarrow \mathbf{R I}$ & 0.330 & 0.318 & 0.103 & 3.208 \\
$\mathbf{R} \rightarrow \mathbf{C S}$ & 0.562 & 0.555 & 0.173 & 3.243 \\
$\mathbf{S E} \rightarrow \mathbf{C S}$ & 0.064 & 0.073 & 0.087 & 0.736 \\
$\mathbf{S E} \rightarrow \mathbf{R I}$ & 0.187 & 0.202 & 0.080 & 2.329 \\
\hline
\end{tabular}

Tabel 5 menunjukkan bahwa hubungan antara CP terhadap CS adalah tidak signifikan, karena Tstatistik sebesar $1.072(<1.65)$. Tabel 5 menunjukkan bahwa hubungan antara CP terhadap RI adalah signifikan, karena T-statistik sebesar 2.494 (>1.65). 
Tabel 5 menunjukkan bahwa hubungan antara CS terhadap RI adalah signifikan, karena T-statistik sebesar 3.208 (>1.65). Tabel 5 menunjukkan bahwa hubungan antara $\mathrm{R}$ terhadap CS adalah signifikan, karena T-statistik sebesar $3.243(>1.65)$. Tabel 5 menunjukkan bahwa hubungan antara SE terhadap CS adalah tidak signifikan, karena T-statistik sebesar 0.736 (<1.65). Tabel 5 menunjukkan bahwa hubungan antara SE terhadap RI adalah signifikan, karena Tstatistik sebesar $2.329(>1.65)$.

\section{Pembahasan}

Self Image Congruence terhadap Customer Satisfaction

Hasil penelitian menunjukkan bahwa Self Image Congruence Broadway Barbershop tidak bepengaruh signifikan terhadap Customer Satisfaction di Broadway Barbershop. Tidak berpengaruh ini dapat dilihat dari nilai original sampel pada tabel uji hipotesis yang menunjukkan nilai positif 0.064 , dengan demikian di Broadway Barbershop terdapat kepercayaan bahwa Self Image Congruence tidak berpengaruh terhadap Customer Satisfaction.

Hal ini terbukti dengan adanya observasi lapangan di Broadway Barbershop, dimana pelanggan yang datang dikarenakan untuk merapikan rambut di Broadway Barbershop adalah sesuai dengan kepribadian mereka, namun bukan dapat membuat mereka puas dengan Broadway, melainkan karena adanya kecocokan kepribadian seorang pelanggan dengan Broadway itu sendiri. Kepribadian atau citra diri seseorang yang positif tidak menimbulkan kepuasan di Broadway Barbershop.

\section{Retail Service Quality terhadap Customer Satisfaction}

Hasil penelitian menunjukkan bahwa Retail Service Quality di Broadway Barbershop berpengaruh signifikan terhadap Customer Satisfaction di Broadway Barbershop. Pengaruh positif dapat dilihat dari nilai original sampel pada tabel uji hipotesis yang menunjukkan nilai positif 0.562 , dengan demikian di Broadway Barbershop terdapat kepercayaan akan Retail Service Quality mempengaruhi Customer Satisfcation.

Hasil ini sesuai dengan penelitian sebelumnya dimana kualitas layanan dan kepuasan yang ditawarkan oleh pemasar pelanggan saling berkaitan. Semakin tinggi kualitas layanan, semakin tinggi kepuasan pelanggan. Kualitas layanan yang ditujukan kepada konsumen merupakan elemen yang sangat penting agar dapat menjamin kelangsungan hidup atau menjaga kestabilan usaha perusahaan atau retail, karena perusahaan atau retail sangat mengharapkan rasa puas dalam diri pelanggan (Tjiptono \& Chandra, 2005).

Customer Perceived Service Quality terhadap Customer Satisfaction

Hasil penelitian menunjukkan bahwa Customer Perceived Service Quality di Broadway Barbershop tidak berpengaruh signifikan terhadap Customer Satisfaction di Broadway Barbershop. Tidak berpengaruh positif ini dapat dilihat dari nilai original sampel pada tabel uji hipotesis yang menunjukkan nilai positif 0.174 , dengan demikian Broadway Barbershop terdapat kepercayaan bahwa Customer Perceived Service Quality tidak berpengaruh terhadap Customer Satisfaction.

Berdasarkan observasi di Broadway Barbershop, persepsi kualitas layanan pelanggan yang baik tidak mempengaruhi kepuasan mereka. Persepsi kualitas layanan yang baik tidak bisa mencerminkan jika pelanggan puas dengan Broadway, karena persepsi akan kualitas layanan di Broadway bisa timbul karena penilaian diri sendiri.

\section{Customer Satisfaction terhadap Repurchase Intention}

Hasil penelitian menunjukkan bahwa Customer Satisfaction di Broadway Barbershop berpengaruh signifikan terhadap Repurchase Intention di Broadway Barbershop. Pengaruh positif juga dapat dilihat dari nilai original sampel pada tabel uji hipotesis yang menunjukkan nilai positif 0.330 , dengan demikian jika terdapat kepercayaan akan Customer Satisfaction maka secara otomatis Repurchase Intention berjalan dengan baik.

Oleh karena itu, dengan adanya kepuasan konsumen terhadap suatu produk atau jasa tertentu dapat mempengaruhi minat pembelian ulang produk atau jasa. Semakin puas konsumen terhadap produk atau jasa tertentu dapat mengakibatkan konsumen melakukan pembelian ulang pada produk atau jasa tersebut.

Self Image Congruence terhadap Repurchase Intention

Hasil penelitian menunjukkan bahwa Self Image Congruence di Broadway Barbershop berpengaruh signifikan terhadap Repurchase Intention di Broadway Barbershop. Pengaruh positif juga dapat dilihat dari nilai original sampel pada tabel uji hipotesis yang 
menunjukkan nilai positif 0.187 , dengan demikian jika terdapat kepercayaan akan Self Image Congruence maka secara otmatis Repurchase Intention akan berjalan dengan baik.

Hasil ini sesuai dengan penelitian sebelumnya dimana Self Image Congruity dapat mempengaruhi minat pembelian ulang karena sesorang memiliki motif untuk berperilaku yang sesuai dengan persepsi dirinya (Ibrahim dan Najjar,2007). Semakin sesuai self image congruity, maka semakin baik pula sikap dan minat beli ulang terhadap produk atau jasa tertentu.

Customer Perceived Service Quality terhadap Repurchase Intention

Hasil penelitian menunjukkan bahwa Customer Perceied Service Quality di Broadway Barbershop berpengaruh signifikan terhadap Repurchase Intention di Broadway Barbershop. Pengaruh positif juga dapat dilihat dari nilai original sampel pada tabel uji hipotesis yang menunjukkan nilai positif 0.300 , dengan demikian jika terdapat kepercayaa akan Customer Perceived Service Quality maka secara otomatis Repurchase Intention akan berjalan dengan baik. Persepsi kualitas konsumen yang baik dapat mempengaruhi kedepannya agar konsumen dapat melakukan pembelian ulang.

\section{KESIMPULAN DAN SARAN}

\section{Kesimpulan}

Sesuai dengan rumusan masalah penelitian dan didasarkan pada hasil pembahasan, makasimpulan yang didapatkan dari penelitian ini adalah sebagai berikut: Self Image Congruity tidak berhubungan signifikan terhadap Customer Satisfaction, Retail Service Quality berhubungan signifikan terhadap Customer Satisfaction, Customer Perceived Service Quality tidak berhubungan signifikan terhadap Customer Satisfcation, Customer Satisfaction berhubungan signifikan terhadap Repurchase Intention, Self Image Congruity berhubunga signifikan terhadap Repurchase Intention, Customer Perceived Service Quality berhubungan signifikan terhadap Repurchase Intention.

Hal ini dikarenakan kepuasa konsumen di Broadway Barbershop hanya dilihat dari kualitas pelayanan, tidak bisa mengukur kepuasan konsumen melalui kesesuaian dengan kepribadian konsumen maupun persepsi konsumen itu sendiri. Adanya kecocokan kepribadian dan persepsi yang baik dari konsumen dapat membuat konsumen tersebut memiliki minat untuk pembelian ulang, tetapi tidak dapat digunakan untuk mengukur kepuasan konsumen. Di lain sisi, kepuasan konsumen akan membuat konsumen memiliki minat untuk pembelian ulang.

\section{Saran}

Adapun saran yang dapat diberikan sebagai hasil dalam penelitian ini adalah sebagai berikut: Berdasarkan penelitian, kualitas layanan yang diberikan oleh Broadway Barbershop kepada konsumen sangat erat kaitannya dengan kepuasan konsumen. Kualitas layanan dapat memberikan dorongan kepada pelanggan untuk menjalin hubungan yang kuat dengan Broadway Barbershop. Dalam jangka panjang hubungan yang terjalin dapat memungkinkan Broadway Barbershop dapat memahami dengan seksama harapan konsumen serta apa yang menjadi kebutuhan konsumen. Broadway Barbershop dapat meningkatkan kepuasa pelanggan dengan cara memaksimumkan pelayanan yang menyenangkan. Untuk merumuskan Standart Operasional Prosedur (SOP) di Broadway Barbershop dapat menggunakan Balance Scorecard (BSC).

\section{DAFTAR PUSTAKA}

Bitner, M., \& Zeithaml, V. (2003). Service Marketing (3rd ed.). New Delhi: Tata McGraw Hill.

Durianto, Sugiarto, \& Sitinjak. (2001). Strategi Menaklukkan Pasar Melalui Riset Ekuitas dan Perilaku Merek. Jakarta: PT. Gramedia Pustaka Utama.

Kaul, S. (2005). Measuring Retail Service Quality: Examining Applicability of International Research Perspectives in India. India: Indian Institute of Management Research and Publications. Kotler, P., \& Keller, K. L. (2009). Manajemen Pemasaran (13th ed.). Jakarta.

Kuncoro, M. (2003). Metode Riset untuk Bisnis dan Ekonomi. Jakarta: Erlangga.

Lindquist, J., \& Sirgy, M. J. (2009). Shopper, Buyer, and Consumer Behavior (4th ed.). Ohio Mason: Cengage Learning.

Malhotra, N. (2004). Marketing research an applied orientation (4th ed.). USA: Prentice Hall.

Mangkunegara, A. P. (2000). Perilaku Konsumen. Bandung: Reika Aditama.

Peter, P. J., \& Olson, J. C. (2002). Perilaku Konsumen dan Strategi Pemasaran (4th ed.). Jakarta: Erlangga. Purwanto. (20011). Statistika untuk penelitian. Yogyakarta: Pustaka Pelajar.

Schiffman, L., \& Kanuk, L. L. (2008). Consumer Behavior (7th ed.). Jakarta: Pt. Indeks. 
Suprapto, J. (2008). Statistik: Teori dan Aplikasi. Jakarta: Erlangga.

Tjiptono, F. (2007). Strategi Pemasaran (2nd ed.). Yogyakarta: Andi Ofset.
Tjiptono, F., \& Chandra, G. (2005). Service Quality Satisfaction. Yogyakarta: Andi.

Zeithaml. (2011). Service Marketing. The Mc Graw Hill Company. 